\title{
FENOMENA KENAKALAN REMAJA DI INDONESIA
}

\author{
Oleh: \\ Puji Lestari \\ FIS UNY
}

\begin{abstract}
Abstrak
Fenomena kenakalan remaja di Indonesia semakin hari semakin menunjukkan hal-hal yang lebih distruktif dan meresahkan kehidupan masyarakat baik dalam lingkup kecil maupun luas. Hal ini dipengaruhi oleh beberapa faktor, yaitu adanya sifat-sifat atau karakteristik genetik yang diturunkan oleh orang tua, serta pengaruh lingkungan yang berkaitan dengan keluarga, sekolah, teman bermain atau lingkungan masyarakat umum. Perkembangan tentang dinamika remaja itu sendiri sangat diperlukan bagi orang tua dan pendidik yang banyak berhubungan dengan mereka. Era globalisasi banyak sekali memunculkan ekses-ekses dalam masyarakat yang berkaitan dengan pola perilakunya. Oleh karena itu, sudah saatnya masyarakat bersama orang tua dan pendidik maupun para profesional menyatukan langkah untuk memahami, mengelola, serta mengajak remaja mengembangkan diri secara positif dan konstruktif sehingga di masa mendatang mereka dapat tumbuh menjadi generasi muda yang dewasa, matang, dan berkualitas.
\end{abstract}

Kata kunci: kenakalan remaja, orang tua, globalisasi

\section{Pendahuluan}

Masa remaja merupakan masa yang selalu dialami oleh setiap manusia. Namun dalam usia remaja ini manusia sedang mengalami proses pembentukan diri menjadi dewasa. Masa remaja memang masa yang riskan akan kegoncangan jiwa dalam arti pada masa ini merupakan masa yang penuh dengan pengaruh untuk memasuki masa dewasa dari masa anak-anak. Pada usia remaja inilah terjadi proses perubahan menuju kepada proses pematangan kepribadian yang penuh dengan pemunculan sifat-sifat pribadi yang sesungguhnya yang harus berbenturan dengan rangsang-rangsang dari luar. Benturan-benturan inilah yang sering menimbulkan persoalan bagi remaja yang lemah mental, jiwa dan rohaninya yang kadang-kadang diwujudkan pada suatu tindakan yang menyimpang.

Tindakan yang menyimpang merupakan problematika yang sering terjadi pada remaja, baik di lingkungan keluarga, sekolah maupun lingkungan masyarakat. Di rumah misalnya adanya tindakan indisiplin, berani dengan orang tua, menentang perintah orang tua, berkelahi dengan saudara dan sebagainya. Di sekolah, ditunjukan dengan tindakan perkelahian antar pelajar, melakukan corat-coret tembok sekolah, 
sering membolos, dan sebagainya. Sedangkan di lingkungan masyarakat sering dilakukan dengan tindakan-tindakan mencuri barang-barang milik orang lain, memalak atau memeras orang untuk menyerahkan uang, melanggar rambu-rambu lalu lintas jalan, dan lain sebagainya.

Tindakan yang menyimpang ini dapat berakibat fatal jika tidak dibarengi dengan penyediaan fasilitas bagi penyaluran hobby sebagai ujud penanganan proses pematangan pribadi remaja. Disamping itu perhatian serius dari berbagai pihak terutama orang tua dan aparat pemerintah akan pemenuhan kebutuhan remaja dalam proses pematangan jiwanya menjadi kunci utama keberhasilan mengatasi problematika remaja.

\section{Problem-problem Remaja}

Pertumbuhan dan perkembangan remaja tidak lepas dari pengaruh bawaan yang berkaitan dengan sifat-sifat atau karakteristik genetika yang diturunkan oleh orang tua, serta pengaruh lingkungan yang berkaitan dengan keluarga, sekolah, teman bermain, atau lingkungan masyarakat umum. Pemahaman tentang dinamika perkembangan remaja amat diperlukan bagi orang tua maupun pendidik yang banyak berhubungan dengan mereka. Betapa tidak, usia remaja di era global ini banyak sekali memunculkan ekses-ekses dalam masyarakat. Kasus-kasus pelecehan seksual, perkosaan, aborsi, tawuran, narkoba, maupun kriminalitas yang melibatkan remaja menjadi berita yang marak di media-media masyarakat. Mengapa kondisi semacam ini terjadi ? usia remaja adalah usia yang ideal untuk proses belajar serta mengeksplorasi dan mengembangkan diri, namun sayang, hal ini menjadi sia-sia karena terjadi penyimpangan-penyimpangan atau gangguan-gangguan perilaku yang harus mereka alami. Sudah saatnya masyarakat bersama orang tua, pendidik maupun profesional menyatukan langkah untuk memahami, mengelola serta mengajak remaja mengembangkan diri secara positif dan konstruktif, sehingga di masa mendatang dapat tumbuh menjadi generasi muda yang dewasa, matang dan berkualitas. Perlu usaha-usaha yang intensif dan integratif dalam memaknai perilaku remaja, tidak saja yang ditampilkan, tetapi juga makna-makna yang seringkali tersembunyi di balik penampilan mereka. Urgensi dalam memahami dinamika perkembangan remaja sesungguhnya merupakan salah satu bentuk perhatian dan 
kasih sayang yang wajar dari orang tua maupun masyarakat terhadap mereka, sehingga remaja dapat merasakan adanya kepedulian keluarga dan lingkungan terhadap keberadaan mereka. Manfaat lain yang dapat diperoleh adalah mengenal dan mengetahui potensi remaja, sehingga orang tua dapat menyalurkan secara tepat minat dan bakat mereka, serta mengantisipasi dan mencegah adanya gejala-gejala gangguan psikososial yang mungkin terjadi. Masyarakat dapat memaknai perilaku remaja dengan cara mengenali dan memahami karakteristik atau ciri khas yang umum dimiliki oleh mereka. Remaja memiliki karakteristik yang tampak menonjol dalam perilaku kesehariannya, seperti: perkembangan usia kronologis berkisar antara 12-18 tahun, lebih banyak menghabiskan waktu bersama teman sebaya, keinginan untuk mandiri, kemampuan untuk memiliki dan memilih banyak rujukan (identifikasi), keinginan berpartisipasi dalam aktivitas-aktivitas kelompok, kurang membutuhkan (menolak) supervisi dari orang tua, cenderung bebas dalam mengekspresikan dan menampilkan diri, membutuhkan penerimaan sosial (masyarakat), serta saling berbagi dengan teman sebaya mengenai keyakinan dan minat sosial.

Remaja menghadapi 2 problem besar. Problem pertama adalah problen intern,ini secara alami akan terjadi pada diri remaja. Hasrat seksual yang berasal dari naluri seksualnya, mulai mendorong untuk dipenuhi. Hal ini sangat fitrah karena fisiknya secara primer maupun sekunder sudah mulai berkembang. Misalnya mulai berfungsinya hormon testosteron pada laki-laki menyebabkan pertumbuhan bulu pada daerah fisik tertentu, berubahnya suara menjadi lebih besar. Atau mulai berfungsuinya hormon progesteron pada perempuan menyebabkan perubahan fisik di dadanya, dan sekaligus mengalami menstruasi. Mengapa ini bisa dikatakan problem? Karena apabila remaja tersebut tidak paham tentang hal ini maka ia tidak mengerti cara merawat dirinya sehingga bisa tumbuh menjadi remaja yang tidak sehat secara fisik. Banyak orang tua yang tidak merasa perlu memahamkan anak remajanya, sehingga ia memiliki kendala dalam berinteraksi dengan temantemannya.

Problem yang kedua adalah problem eksternal. Inilah yang terkatagori dalam pembentukan lingkungan tempat remaja berkiprah. Faktor penting yang membuat remaja memiliki masalah dalam pergaulannya adalah faktor pemikiran dan faktor 
rangsangan.Pemikiran adalah sekumpulan ide tentang kehidupan yang diambil dan dipenetrasikan oleh remaja itu ke dalam benaknya sehingga menjadi sebuah pemahaman yang mendorong setiap perilakunya. Pemikiran penting yang membentuk remaja adalah: makna kehidupan, standar kebahagiaan hidup, dan standar perilaku.Misalnya ketika seorang remaja memahami bahwa makna kehidupan ini adalah materi, kebahagiaan adalah kekayaan, dan standar perilaku adalah yang penting, maka kita akan menemukan remaja seperti ini tidak akan memahami resiko perbuatannya. Baginya mencuri, narkoba sambil mendagangkannya, seks bebas adalah kenikmatan dan tujuan hidupnya. Remaja seperti ini akan banyak kita temukan dalam lingkungan masyarakat sekuler (menjauhkan diri dari agama). Ia hidup diliputi dengan hal-hal yang berbau Materialisme. Bagaimana tontonan kesehariannya adalah acara konters-kontes agar menjadi tenar dan kaya, tanpa perlu ilmu apalagi intelektualitas tinggi. Rangsangan pornografi dan pornoaksi menjadi konsumsi kesharian. Maka dari sinilah muncul problem besar remaja.

Ada tiga pihak yang harus diberikan jalan keluar masalah remaja. Pihak pertama adalah orang tua atau keluarga. Orang tua wajib membekali diri dengan ilmu dalam mendidik anak. Pihak kedua adalah remaja itu sendiri. Remaja harus membiasakan diri dengan perilaku selektif dalam memilih tempat bergaul. Ini penting karena perkembangan seksual yang alami dalam dirinya akan berkaitan erat dengan kadar informasi seksual yang ia dapatkan dalam kehidupannya. Apabila ia memilih pergaulan yang tidak pernah absen menonton ved porno, berkata jorok, campur baur laki-laki dan perempuan tanpa aturan, dan terbiasa mengkoleksi bukubuku bacaan porno, maka remaja ini akan jatuh ke dalam pergaulan seks bebas. Pihak ketiga adalah negara. Negara adalah kepemimpinan masyarakat secara umum. Wewenang besar ada pada negara dalam menerapkan model dan macam aturan untuk masyarakatnya. Apabila sebuah negara lebih memilih model negara korporasi (kapitalis, pedagang dan pebisnis untuk rakyatnya), maka ia akan menerapkan aturan yang berdampak pada keuntungan bisnis dengan dalih untuk masukan negara. Misalnya dibolehkannya majalah porno semacam play boy dan tayangan porno dalam bidang hiburan, ini tidak dapat dilepaskan dari aturan yang sudah disahkan 
oleh pemerintah itu sendiri. Bagi negara semacam ini masalah dampak kepada masyarakat bukanlah suatu yang diperhitungkan.

\section{Gejala-gejala Kenakalan Remaja}

Pembahasan gejala kenakalan remaja lebih ditekankan kepada berbagai hal yang memungkinkan adanya kenakalan remaja di masyarakat. Kenakalan remaja sebagai gejala sosial sebagian dapat diamati serta diukur kuantitas dan kualitas kejahatannya, namun sebagian lagi tidak bisa diamati dan tetap tersembunyi hanya dirasakan dampaknya.

Dalam kondisi dinamis, gejala kenakalan remaja merupakan gejala yang terus menerus berkembang, berlangsung secara progresif sejajar dengan perkembangan teknologi, industrialisasi dan urbanisasi. (Kartini Kartono, 1992: 23). Dengan meningkatnya kemajuan teknologi yang terjadi di masyarakat dunia, pada kenyataannya kejahatan anak-anak dan remajapun semakin meningkat pula.

Tumbuh dan berkembangnya kejahatan anak remaja pada kenyataannya berbarengan dengan perkembangan penduduk, industrialisasi, urbanisasi dan kemajuan ilmu pengetahuan dan teknologi. Dengan demikian kejahatan anak remaja atau kenakalan remaja merupakan gejala sosial yang terdapat di masyarakat umum. Bila ditelusuri secara mendalam perkembangan kejahatan anak remaja atau kenakalan remaja sebagai gejala sosial banyak dipengaruhi oleh berbagai hal dalam kehidupan masyarakat, mulai dari lingkungan yang paling kecil yaitu keluarga hingga masyarakat luas.

1. Kehidupan Keluarga yang merupakan Persemaian bagi Tumbuhnya Kenakalan Remaja

Tumbuhnya kenakalan remaja dapat diketahui dari gejala yang ada dalam kehidupan masyarakat. Berbagai segi kehidupan mewarnai berjalannya kehidupan masyarakat secara keseluruhan, dan segi kehidupan yang dapat merupakan persemaian bagi tumbuhnya kenakalan ramaja diawali dari lingkungan yang paling kecil yaitu keluarga. Keluarga merupakan lingkungan 
primer bagi setiap individu, mulai dari ia lahir hingga meninggalkan rumah untuk membentuk keluarga sendiri.

Sebagai lingkungan primer, keluarga tempat pertama kali terjadinya hubungan antar manusia yang paling intensif dan paling awal. Hubungan antara suami dengan istri, hubungan antara anak dengan orang tuanya, serta hubungan antara anak dengan anak. Namun yang paling penting dalam keluarga itu adalah untuk pertama kalinya anak mengenal lingkungan keluarganya sebelum dia mengenal lingkungan yang lebih luas. Sebelum anak mengenal nilai-nilai dan norma-norma yang ada dalam masyarakat, ia mengenal terlebih dahulu nilai-nilai dan norma-norma yang berlaku dalam keluarga untuk dijadikan bagian dari kepribadiannya. Hal inilah yang sering bisa diamati adanya perbedaan pola perilaku anak-anak dari keluarga kelas sosial atas dengan anak-anak dari keluarga kelas social bawah. Bahkan agama dan pendidikan dalam keluargapun dapat mewarnai perilaku seseorang. Kesemuanya itu pada hakekatnya ditimbulkan oleh nilai dan norma yang berlaku dalam keluarga yang diturunkan melalui pendidikan dan pengasuhan orang tua terhadap anak-anak secara turun temurun.

Keluarga pada jaman dahulu dengan keluarga pada jaman sekarang sangatlah berbeda. Pada jaman dahulu, keluarga memiliki kedudukan sebagai satu kesatuan kekeluargaan yang besar yang disebut famili. Segala kebutuhan hidup seperti makanan, pakaian, alat-alat rumah tangga dicukupi oleh famili secara gotong royong. Pendidikan yang diberikan kepada anak-anak dalam famili merupakan kelanjutan adat istiadat yang diperoleh dari nenek moyang secara turun temurun. Pendidikan berjalan hampir tidak ada perubahan sama sekali karena segalanya diterima sebagai sesuatu yang benar dan didasarkan pada adat istiadat. Anak-anak melaksanakan apa yang ia terima dengan patuh tanpa didasarkan pertimbangan pemikiran yang lebih luas. Sedangkan kondisi keluarga pada jaman sekarang telah menjadi keluarga yang terpecah menjadi keluargakeluarga kecil. (Soerjono Soekanto menyebutnya keluarga batih). Perubahan dan perkembangan kemajuan ilmu pengetahuan dan teknologi menuntut keluargakeluarga tersebut untuk mampu menyesuaikannya. Hal tersebut memberikan dampak pada orang tua lebih bertanggung jawab moral terhadap pendidikan anak-anaknya, dan pula menjadikan keluarga-keluarga menampilkan pola-pola 
perilaku adaptif dengan berbagai bentuk dan intensitasnya. Dalam kondisi demikian pendidikan terhadap anak merupakan problematika yang serba sulit. Kesulitan ini muncul karena keadaan sekarang yang merupakan keadaan ke arah modernisasi kadang bertentangan dengan nilai-nilai tradisional yang sudah lekat dengan orang tua, sedangkan orang tua lebih banyak memikirkan pemenuhan kebutuhan hidup yang semakin kompleks, maka kesulitan akan muncul dari orang tua dalam menentukan cara terbaik dalam membimbing anak dalam keluarganya. Kesulitan ini akan semakin dirasakan orang tua bila kewibawaan orang tua merosot karena bercerai, penjudi, pemabuk, dan sikap sarkasme dalam kehidupan keluarga. Orang tua tidak mempunyai otoritas terhadap perilaku anak, sehingga pengawasan dan kontrol orang tua sebagai kendali bagi perkembangan fisik dan psikis anak harus ekstra hati-hati dan cermat, karena hal tersebut akan menentukan corak perkembangan pribadi anak.

Pola perilaku anak yang menyimpang dapat disebabkan oleh pendidikan keluarga yang tidak bisa memberikan kasih sayang. Sikap hidup orang tua yang penuh kekerasan memberikan pengalaman hidup bagi anak dan sewaktu-waktu dapat direproduksi dan direfleksikan dalam kehidupan anak di luar keluarganya seperti bentuk perilaku jahat atau biasa disebut delinquency.

Gejala yang nampak dalam kehidupan keluarga pada jaman sekarang adalah anak sebagai pemegang kunci dan bukannya orang tua. Kesibukan orang tua di luar rumah merupakan salah satu penyebab gejala tersebut. Anak dapat menentukan dirinya sendiri dan bahkan mengabaikan peran orang tua sehingga anak merasa bebas untuk menentukan sikap dan menuruti kata hatinya meskipun bertentangan dengan norma-norma kekerabatan. Anak memiliki otoritas terhadap perkembangan diri sendiri dengan satu asumsi bahwa gejala melemahnya peran orang tua terhadap pembentukan pribadi anak sebagai perwujudan paham individualis yang memandang keluarga lambat laun akan mengalami disintegrasi. Orang tua akan kehilangan alternatif dalam memegang otoritas kepada anak sehingga memberikan jalan bagi anak untuk memiliki kebebasan penuh.

Delinkuensi remaja bukan merupakan peristiwa herediter, bukan merupakan warisan bawaan sejak lahir. Banyak bukti menyatakan bahwa tingkah laku a-susila dan kriminal orang tua serta anggota keluarga lainnya memberikan 
dampak menular dan infeksius pada jiwa anak-anak. (Kartini Kartono, 1992: 58). Anak melakukan pencurian misalnya, hal ini bukanlah merupakan sifat bawaan sejak lahir ataupun kebisaaan mencuri yang diwariskan kepada anak sebagai ciriciri karakteristik yang herediter, melainkan terjadi karena proses pengkondisian atau proses pembentukan kebiasaan dalam kehidupan sehari-hari dalam keluarga, karena meniru pola kriminal ayah, ibu atau salah seorang anggota keluarganya. Oleh karena itu keluarga memiliki peranan penting dalam perkembangan anak, keluarga yang baik akan berpengaruh positif bagi perkembangan anak, sedangkan keluarga yang jelek akan berpengaruh negatif bagi perkembangan anak. Gangguan pada pertumbuhan kepribadian seseorang sangat mungkin disebabkan oleh pecahnya kehidupan keluarga secara fisik maupun mental.

Sebagai unit pergaulan hidup terkecil dalam masyarakat, keluarga mempunyai peranan-peranan tertentu (Soerjono Soekanto, 2004: 23), yaitu:

a. keluarga berperanan sebagai pelindung bagi pribadi-pribadi yang menjadi anggota, di mana ketenteraman dan ketertiban diperoleh dalam wadah tersebut;

b. keluarga merupakan unit social-ekonomis yang secara materiil memenuhi kebutuhan anggota-anggotanya;

c. keluarga menumbuhkan dasar-dasar bagi kaidah-kaidah pergaulan hidup;

d. keluarga merupakan wadah di mana manusia mengalami proses sosialisasi awal, yakni suatu proses di mana manusia mempelajari dan mematuhi kaidahkaidah dan nilai-nilai yang berlaku dalam masyarakat.

Dengan mencermati peranan keluarga di atas, maka keluarga juga mempunyai andil yang besar bagi tumbuhnya kenakalan remaja. Beberapa hal tentang kondisi keluarga yang merupakan persemaian bagi tumbuhnya kenakalan remaja sebagaimana dikemukakan oleh Kartini Kartono (1992: 58 - 63), antara lain:

a. Pola kriminal ayah, ibu atau salah seorang anggota keluarga

Pola kriminal ayah, ibu atau salah seorang anggota keluarga dapat mencetak pola kriminal hampir semua anggota keluarga lainnya. Oleh karena itu tradisi, sikap hidup, kebisaaan dan filsafat hidup keluarga itu besar sekali pengaruhnya dalam membentuk tingkah laku dan sikap setiap anggota 
keluarga. Tingkah laku kriminal orang tua mudah sekali menular kepada anakanaknya. Perilaku kriminal ini sangat mudah dioper oleh anak-anak puber dan adolesens yang belum stabil jiwanya dan tengah mengalami banyak gejolak batin.

b. Temperamen orang tua

Temperamen orang tua, terutama dari ayah yang agresif meledak-ledak, suka marah dan sewenang-wenang, serta kriminal, tidak hanya akan mentransformasikan defek temperamennya saja, akan tetapi juga menimbulkan iklim yang mendemoralisir secara psikis. Sekaligus juga merangsang reaksi emosional yang sangat impulsive kepada anak-anaknya. Pengaruh demikian menjadi semakin buruk terhadap jiwa anak-anak remaja dan adolesens, sehingga mereka mudah dijangkiti kebiasaan kriminal.

c. Kualitas rumah tangga

Kualitas rumah tangga atau kehidupan keluarga jelas memainkan peranan paling besar dalam membentuk kepribadian remaja delinkuen. Rumah tangga yang berantakan, misalnya karena kematian ayah atau ibu, perceraian bapak dengan ibu, hidup terpisah, poligami, ayah mempunyai istri simpanan, keluarga yang diliputi konflik keras, semua itu merupakan sumber yang subur untuk memunculkan delinkuen remaja.

d. Anak-anak kurang mendapat perhatian dan kasih sayang.

Anak-anak yang kurang mendapatkan perhatian dan kasih sayang dari orang tuanya selalu merasa tidak aman, merasa kehilangan tempat berlindung dan tempat berpijak. Suatu saat anak-anak tersebut akan mengembangkan reaksi kompensatoris dalam bentuk dendam dan sikap bermusuhan terhadap dunia luar. Anak-anak tersebut mulai menghilang dari rumah, lebih suka bergelandangan dan mencari kesenangan hidup yang imaginer di tempattempat lain. Mereka mulai berbohong dan mencuri untuk menrik perhatian dan mengganggu orang tuanya, atau mereka mulai mengembangkan reaksi kompensatoris negative untuk mendapatkan keenakan dan kepuasan hidup dengan melakukan perbuatan kriminal.

e. Sikap ketidakpuasan terhadap orang tua 
Sikap ketidakpuasan terhadap orang tuanya adakalanya ditunjukkan secara terang-terangan, dan bisaanya dimulai dengan melawan atau memberontak sambil melakukan perbuatan destruktif merusak yang tidak terkendali. Sikap demikian ditunjukkan oleh anak-anak yang merasa tidak bahagia dan dipenuhi banyak konflik batin serta mengalami frustasi terus-menerus. Anak-anak yang demikian akan mulai mengadakan serangan-serangan kemarahan ke dunia sekitar, menteror lingkungan, merampok milik orang lain dan sebagainya. Semua itu dilakukan sebagai perbuatan penyalur atau pelepas bagi semua ketegangan, kerisauan dan dendam hatinya. Penolakan orang tua atau ditinggalkan oleh salah seorang dari kedua orang tuanya, jelas menimbulkan emosi dendam, rasa tidak percaya karena merasa dikhianati, kemarahan dan kebencian. Sentiment hebat itu mengambat perkembangan relasi manusiawi anak, kemudian muncullah disharmoni social dan lenyapnya control diri, sehingga anak dengan mudah bisa dibawa oleh arus buruk lalu menjadi kriminal. Anak-anak delinkuen memang sadar, akan tetapi yang dikembangkan justru kesadaran yang salah.

Secara umum dapat dinyatakan bahwa anak delinkuen ataupun kenakalan remaja (juvenile delinquency) datang dari rumah tangga atau keluarga dengan relasi manusiawi penuh konflik dan percekcokan yang disharmonis. Situasi dan kondisi lingkungan awal anak, yaitu keluarga mempengaruhi pembentukan pola delinkuen anak-anak dan remaja. Kualitas dan agresivitas dari perilaku kriminal anak-anak dan para remaja pada hakekatnya merupakan produk kebisaaan keluarga yang tidak terpuji, yang berakibat anak-anak menolak norma dan konvensi pergaulan hidup yang umum berlaku sehingga menjadi kriminal.(Kartini Kartono, 1992: 63, 65).

2. Struktur Masyarakat Modern yang dapat menimbulkan Kenakalan Remaja

Dengan semakin berkembangnya ilmu pengetahuan dan teknologi, maka semakin berkembang pula kehidupan masyarakat menuju ke masyarakat modern. Modernitas ditandai dengan semakin banyaknya ketergantungan anggota masyarakat kepada teknologi. Hampir setiap aktivitas individu dalam masyarakat yang semula dikerjakan secara manual beralih dengan 
menggunakan mesin-mesin. Dengan kata lain terjadi perubahan dari pekerjaan manual ke pekerjaan electrical. Perubahan demikian berpengaruh sangat kompleks dalam kehidupan masyarakat, seperti banyaknya pengangguran, perubahan struktur keluarga, dan urbanisasi yang pada prinsipnya akan merubah pada hampir semua aspek kehidupan manusia.

Sebagaimana dikemukakan di atas, bahwa perubahan masyarakat menuju kepada masyarakat modern berpengaruh pula pada perubahan struktur keluarga dari struktur keluarga tradisional yang bersifat extended family berubah kepada struktur keluarga yang bersifat nuclear family. Dengan demikian akan berpengaruh pula pada corak kehidupan ekonomi baru dan gaya hidup di masyarakat.

Dengan terjadinya perubahan masyarakat ke arah modernisasi juga berdampak pada cepatnya perubahan minat, dan cara berfikir. Anak-anak dan remaja cenderung lebih cepat menerima inovasi dibandingkan dengan orang dewasa dalam mengikuti perubahan, setidak-tidaknya dalam bidang yang mereka pandang penting.

Dalam struktur masyarakat modern anak remaja dianggap masih relative muda, dan mereka kurang diikutsertakan dalam kegiatan orang dewasa, seperti kehidupan politik, kemasyarakatan dan perekonomian. Akibatnya aktivitas para remaja berpaling pada kegiatan kelompok sebayanya di luar rumah untuk memperoleh dukungan identitas dirinya. Kelompok sebaya makin menjadi sumber pengaruh yang kuat bagi kehidupan remaja dalam masyarakat modern. Kehidupan mereka dalam kelompok memiliki ikatan kekeluargaan yang kokoh, intim bergotong royong, bahkan saling melindungi antara anak satu dengan lainnya.

Kehidupan masyarakat modern banyak diwarnai dengan berbagai keramaian-keramaian siang maupun malam. Dunia modern seolah tidak ada batas waktu aktivitas manusia siang dan malam. Dengan keramaian tersebut anak-anak remaja kurang mendapat perhatian, pengawasan dan kasih sayang orang tua, dan mereka dapat melampiaskan kepuasan batin bersama teman sebaya. 
Kehidupan masyarakat modern juga berdampak pada munculnya kesenjangan social ekonomi yang mencolok antara keluarga kelas orang kaya dengan kelas menengah dan miskin. Hal ini dapat pula memicu tumbuhnya kenakalan remaja. Masyarakat modern yang serba materialistis merangsang hasrat kepemilikan melalui ambisi materiil yang tinggi dari orang yang mengamatinya, dan karena keterbatasan ekonomi rendah maka orang lain termasuk para remaja harus mengubur dalam-dalam ambisinya tersebut. Bila para remaja tersebut tidak mampu mengendalikan ambisinya maka persaingan untuk bisa menjadi kaya kadang-kadang ditempuh dengan cara inkonvensional, seperti memeras, menjambret, mencuri, merampok, sampai pada taraf membunuh.

Bagi anak remaja yang berasal dari kelas ekonomi rendah terbentuk oleh keadaan ekonomi yang serba kurang, keterampilan yang minim dan pendidikan yang relative rendah, dan umumnya mereka memiliki tempat tinggal yang tingkat kepadatan penduduknya tinggi, banyak penyakit dan pengangguran, serta dikontraskan dengan kondisi di luar yang menyajikan kemewahan dan kegemerlapan yang dapat dilihatnya melalui pengamatan langsung maupun melalui media elektronik dapat memberikan rangsangan yang kuat kepada anak-anak remaja tersebut untuk berbuat jahat.

Sedangkan bagi anak remaja kelas menengah ke atas yang berdomisili di kota-kota besar yang pada umumnya memiliki banyak waktu luang, dan untuk mengisinya ada kemungkinan digunakan sekedar iseng, seperti mabukmabukan, kebut-kebutan di jalan raya, penggunaan obat terlarang, bergadang di jalan raya, pergi ke diskotik, dan sebagainya. Penyaluran yang dilakukan remaja ini memang penyimpang dari norma umum, sehingga ada yang menamakannya sebagai bentuk kenakalan ramaja. Kenakalan remaja yang dilakukan oleh remaja kelas menengah ke atas di kota-kota besar banyak didorong oleh kebutuhan untuk menonjolkan egonya. Tindakan-tindakan asosial pada hakekatnya dilakukan untuk menghilangkan kejenuhan dalam mengisi kekosongan hati untuk mendapat kepuasan. 
Beberapa hal yang menjadi ciri dari masyarakat modern yang mendorong timbulnya kenakalan remaja (Kartini Kartono, 1992: 79 - 94), antara lain:

a. Perubahan Struktur Keluarga

Dalam kehidupan masyarakat modern terjadi perubahan struktur keluarga ke arah keluarga yang sulit untuk memiliki kemampuan menjaga keteraturan social dan memberikan arah adaptasi terhadap perubahan social. Keluarga semakin sulit peranannya sebagai institusi social yang mampu meredam perbedaan pendapat dan perbedaan kepentingan para anggotanya. Hal ini disebabkan oleh karena masalah-masalah yang berkembang di dalam keluarga terkait erat dengan situasi yang berkembang dalam masyarakat luar.

Pada masyarakat modern, pemerintah banyak mengambil oper fungsifungsi mengasuh serta mendidik anak-anak dan remaja lewat system pendidikan yang semula dilakukan oleh keluarga. Hal ini berakibat pada ikatan-ikatan akrab diantara anak dengan orang tua yang dapat memberikan kualitas personal dan imperative sifatnya untuk membangun tali cinta kasih sayang yang timbal balik dan disiplin di tengah keluarga menjadi berkurang atau menipis, bahkan pada banyak kasus bisa musnah sama sekali.

Dengan demikian masing-masing individu dalam keluarga akan berperilaku sesuai dengan kemampuannya sendiri. Oleh karena itu dapat dipahami bahwa pengaruh social yang keras dan kejam bisa merusak struktur keluarga, terutama mental remaja yang semula akrab intim dan penuh kasih sayang.

Pengaruh social yang keras dan kejam dapat menimbulkan konflik social yang tajam, dan ini berdampak pada tingkat delinkuensi semakin tinggi dan bertambah, khususnya di daerah-daerah yang mengalami proses perubahan yang cepat. Oleh karena itu di Negara-negara yang sangat maju secara ekonomis dan teknologis, tingkat delinkuensinya juga paling tinggi di dunia, seperti misalnya Amerika Serikat, Jepang, Inggris, Swedia dan lain-lain 


\section{b. Frustasi dan Penyimpangan Sosial}

Kehidupan masyarakat modern memberikan warna kehidupan manusia seolah-olah penuh kemewahan dan kemakmuran. Masyarakat modern menuntut semua lapisan masyarakat berpacu untuk menyesuaikan diri dengan lingkungannya. Di tengah-tengah pesatnya perubahan modernisasi dan industrialisasi struktur masyarakat mengalami perubahan juga dimana masyarakat menjadi individualis dan bersifat serba cepat, dan dalam kondisi demikian banyak orang yang mengalami ketidakpastian diri.

Persaingan hidup yang semakin keras guna mencapai kebutuhan hidup dan kepuasan hidup seperti lapangan kerja dan pergaulan social semakin sempit kesempatannya untuk meraih sukses, tidak jarang dari masyarakat modern termasuk anak-anak remaja menaruh rasa frustasi dan kekecewaan karena ketidakmampuannya untuk menyesuaikan dengan kondisi masyarakat tersebut.

Masyarakat modern yang penuh ambisi dan individualis sebagai akibat dari perubahan struktur social, membawa semakin besar proporsi anak remaja yang menggunakan pola tingkah laku delinkuen untuk mampu bersaing dalam kehidupan modern. Masyarakat modern juga membawa akibat lunturnya nilai-nilai tradisi dan control social yang mengakibatkan anak-anak remaja putus kendali.

Masyarakat modern berarti juga kental dengan pusat-pusat industrialisasi yang serba otomatis. Di pusat industri, anak laki-laki pada umumnya menduduki tingkat kejahatan lebih tinggi daripada anak perempuan. Anak laki-laki dalam masyarakat modern yang industrialis lebih banyak bersama ibunya di rumah dibandingkan bersama ayahnya, karena si ayah banyak waktu untuk mencari nafkah di luar rumah. Perilaku ibu terhadap anak laki-lakinya akan terbawa dan sedikit perilaku kejantanan yang tampak dari figure seorang ayah. Setelah memasuki masa puber atau remaja, anak laki-laki diharapkan mampu menggeser identifikasi ibu dengan identifikasi terhadap ayah. Pergeseran identifikasi tersebut menimbulkan banyak tekanan jiwa yang hebat dan krisis identitas anak laki-laki khususnya dalam usaha menegakkan kejantanannya. 
Dalam kondisi kesulitan dan tekanan batin mengakibatkan kepanikan jiwa itulah sebabnya banyak anak laki-laki yang mengalihkan pola tingkah lakunya sehari-hari pada perilaku delinkuen. Sedangkan anak perempuan tidak banyak mengalami goncangan jiwa karena mereka sudah sesuai dengan identifikasi seorang ibu yang feminim. Anak perempuan tidak banyak menderita krisis identitas seprti anak laki-laki dalam masyarakat kota yang modern. Anak perempuan pada umunya tidak suka melakukan tindak berandalan. Mereka lebih suka mendambakan kehangatan dan sekuritas. Sifat kewanitaannya lebih mendorong mereka bersikap pasif. Karena itu perilakunya tidak diarahkan pada perbuatan kekerasan, keberandalan dan kajahatan, dan kurang suka memasuki geng delinkuen. Kartini Kartono (1992: 89) menyatakan bahwa anak perempuan yang mengalami frustasi berat, dan menderita sama parahnya dengan anak lakilaki, dapat mengkompensasikan kepahitan hati serta kekecewaannya pada (1) perilaku pomiskuous (seks bebas dengan siapa saja), (2) prostitusi atau pelacuran, dan (3) melarikan diri dalam kondisi "sakit" yang akan berkembang menjadi gangguan (panyakit) jiwa. Mereka pada umunya tidak suka melakukan agresif dan kriminal.

Namun pada masyarakat modern saat ini dengan dalih emansipasi tidak jarang pula jumlah kejahatan yang dilakukan oleh anak perempuan cenderung meningkat. Hal ini dilakukan oleh anak perempuan biasa juga berangkat dari unsur keterpaksaan dan bukan karena dari tujuan utama kejahatan murni.

3. Pergeseran kota ke desa dan perbedaan ekonomi

Pergeseran dan perluasan kota akan semakin kompleks bila tidak diimbangi oleh adanya perencanaan tata ruang yang tepat. Dalam perspektif tata ruang kota oleh sejumlah elite birokrasi mungkin sudah mempertimbangkan dengan perencanaan yang matang dengan memperhatikan segala aspek, baik aspek ekonomi, sosial, politik maupun kultural. Namun kadang aspek kepentingan pribadi maupun kelompok akan mengalahkan aspek-aspek itu semua, karena didasarkan pada prinsip 
komersial, sehingga sering terjadi urbanisasi besar-besaran yang menyebabkan kepadatan penduduk di kota yang berdampak pada kehidupan yang pengap. Orang-orang kota pada posisi kelas atas merasa terdesak karena suasana pengap, kemudian mereka pindah ke luar kota dan membangun perumahan di pinggiran kota atau daerah sub-urban. Kondisi ini banyak berpengaruh kepada masyarakat desa atau sub-urban dengan munculnya kecemburuan sosial. Mereka yang bisa mengakomodasi kesenjangan sosial tersebut akan berperilaku adaptif, namun bagi yang tidak bisa akan berperilaku non-adaptif yang dapat menyebabkan terjadinya kekerasan. Kekerasan yang terjadi mempunyai indikasi masyarakat termasuk anak-anak remaja.

Kesenjangan sosial yang tampak akan sangat dirasakan bila kelompok ekonomi kuat maupun lemah tidak mampu beradaptasi dan saling curiga. Kecemburuan sosial kelompok masyarakat ekonomi lemah akan semakin tinggi. Namun apabila kesenjangan sosial itu masih bisa diterima oleh lapisan masyarakat ekonomi bawah dan masih berada dalam ambang batas toleransi, maka kesenjangan sosial tersebut tidak akan menjadi masalah sosial, dan ketika kesenjangan itu mulai dipahami sebagai eksploitasi yang dianggap di luar ambang batas toleransi, maka amat potensial dapat menimbulkan kekerasan dan kenakalan remaja.

Kesenjangan sosial yang terjadi dapat menimbulkan kekecewaan, dan ini merupakan bentuk dari apa yang tidak sesuai dengan kenyataan, baik berupa ekonomi, politik maupun kultural. Wajah masyarakat desa sudah berbaur dengan wajah masyarakat kota, artinya desa tidak, kotapun tidak. Karakteristik yang menonjol dari masyarakat ini adalah suburnya tindak kekerasan, kekacauan, termasuk kenakalan remaja, yang lebih meningkat dibanding dengan sebelum kedatangan masyarakat kota. Terlebih lagi bila desa tersebut diubah menjadi kota satelit yang penuh dengan industri, maka akan lebih kompleks lagi masalahnya.

Pergeseran dari desa ke kota atau sebaliknya dengan kondisi sebagaimana diuraikan di atas dapat menyebabkan anak-anak remaja dari keluarga kelas ekonomi rendah kurang mendapat tuntutan hidup berdisiplin 
dan susila dari orang tuanya. Demikian juga anak-anak remaja dari kalangan miskin kurang memiliki bekal untuk bersaing dengan anak-anak remaja dari ekonomi menengah keatas. Kekecewaan yang selalu menghantui anak remaja kurang mampu akan mengalami frustasi berat dan tekanan batin, karena anak remaja tersebut dikondisir oleh banyaknya rintangan, frustasi dan tekanan batin sehingga akan remaja tersebut sering menolak segala norma sosial serta hukum. Hal ini dilakukan sebagai kompensasi dari rasa ketidak adilan terhadap masyarakat yang sosial ekonominya tinggi, dan sebagai gantinya mereka mempraktekkan subkultur delinkuen yang dianggap sebagai prestasi tersendiri.

Sub-kultur delinkuen yang demikian kemudian dikembangkan menjadi suatu perkumpulan geng yang berafiliasi dalam bentuk-bentuk kekerasan, kekejaman, pemberontakan, pelanggaran hukum, agresifitas serta bentuk-bentuk kriminal yang lain. Anak-anak remaja yang bergabung dalam geng ini melapaskan diri dari anak-anak normal dan masyarakat baik-baik, kemudian mencari solusi dengan cara yang tidak wajar yaitu dalam bentuk kriminal. Perilaku yang ditampilkan anak-anak remaja ini pada mulanya merupakan upaya untuk menarik perhatian orang tua, seperti sok jagoan.

Upaya lain yang dilakukan anak-anak remaja adalah menegakkan egonya yang dianggap terancam dan tersisih secara tidak adil dan mencari bobot bagi kehidupannya. Pola hidup yang demikian apabila dibiarkan dan tanpa kontrol serta kendali, pada akhirnya dapat menjadi kebiasaan buruk yang kemudian menjadi benar-benar kriminal.

4. Pengaruh Budaya Asing yang menyebabkan timbulnya Kenakalan Remaja

Modernisasi saat ini sering dikaitkan dengan globalisasi, dikarenakan modernisasi yang membawa kemajuan pada ilmu pengetahuan dan teknologi menjadikan hubungan antar manusia di suatu tempat dengan manusia lain di tempat lain, antara manusia di suatu negara dengan manusia lain di negara lain serasa mudah dan dekat, serta seolah-olah tidak ada batasnya. Hal inilah yang menjadikan pengertian globalisasi memiliki 
banyak penafsiran dari berbagai sudut pandang. Sebagian orang menafsirkan globalisasi sebagai proses pengecilan dunia atau menjadikan dunia sebagaimana layaknya sebuah perkampungan kecil. Sebagian yang lain menyebutnya bahwa globalisasi adalah upaya penyatuan masyarakat dunia dari sisi gaya hidup, orientasi, dan budaya. Globalisasi menyentuh berbagai aspek kehidupan, antara lain seni dan budaya.

Namun yang perlu diperhatikan pula pernyataan bahwa globalisasi dalam kerangka Barat yang ingin menyamakan budaya rakyat dunia. Hal ini sebagai suatu kenyataan saat ini, bahwa kemajuan teknologi banyak diperoleh dan disebarkan oleh negara-negara Barat (Western), sehingga sering orang menyamakan dengan globalisasi identik dengan westernisasi.

Terlepas dari semua itu pada kenyataannya bahwa dengan kemajuan teknologi informasi saat ini memudahkan masuknya berbagai pengaruh asing kedalam negeri termasuk pengaruh budaya asing. Modernisasi yang diikuti dengan kemajuan teknologi informasi akan membawa dampak pada masuknya budaya asing ke dalam negeri atau sebaliknya akan semakin cepat. Dengan mudahnya budaya asing masuk ke dalam negeri yang tentunya akan berpengaruh pada budaya lokal milik masyarakat setempat.

Globalisasi dan perkembangan ilmu pengetahuan dan teknologi yang begitu pesat, teknologi informasi dan komunikasi terutama internet, dapat mempercepat masuk dan berkembangnya budaya asing ke dalam kehidupan masyarakat Indonesia. Pengaruh budaya asing tersebut banyak yang tidak sesuai dengan kebudayaan kita, dan dapat merusak ketahanan nasional, karena mempercepat dekulturisasi yang bertentangan dengan nilai-nilai yang terkandung dalam Pancasila. Masyarakat daerah perbatasan cenderung lebih cepat terpengaruh oleh budaya asing, dikarenakan intensitas hubungan lebih besar dan kehidupan ekonominya sangat tergantung dengan negara tetangga. ( Eddy Sianturi \& Nafsiah,, buletinglitbang@dephan.go.id. 14 Maret 2007)

Bangsa Indonesia adalah bangsa yang begitu mudah menyerap budaya asing. Hal ini dikarenakan (imponk.blogsome.com/2005/04/01/ibukartini-maafkan-kami/): 
a. bangsa Indonesia merupakan bangsa yang majemuk yang terdiri dari banyak suku.

b. masyarakatnya yang plural yang selalu ingin maju.

c. kebudayaan harus terus bekembang dan mereka berhak menyerap setiap budaya yang dibawa oleh orang asing.

d. keterbukaan warganya akan hal-hal yang baru yang dibawa dari luar.

Masuknya budaya asing ke dalam negeri pasti akan membawa pengaruh terhadap pola perilaku masyarakat setempat, dan pengaruh tersebut akan menimbulkan dampak positif maupun negatif. Bila pengaruh budaya asing itu berdampak postif pasti akan membawa kemajuan dan kebaikan hidup masyarakat setempat, namun bila berdampak negatif maka kehancuranlah yang akan diperolehnya. Yang jelas, bila diamati secara baik, budaya asing berpotensi mengubah cara berpikir, cara bekerja dan cara hidup kita, bahkan dapat merubah kebudyaan yang sudah ada.

Perubahan kebudayaan juga dapat menimbulkan akibat-akibat yang tidak terduga-duga dan sering merusak. Bila mayarakat ingin mempertahankan kebudayaannya, maka masyarakat harus berhasil menciptakan keseimbangan antara kepentingan para anggotanya dan tuntutan masyarakat sebagai keseluruhan. Untuk mencapai itu, masyarakat menawarkan imbalan kepada yang tunduk kepada patokan-patokannya, dan biasanya mungkin berbentuk pengakuan sosial (William A Haviland, 1988: $351)$.

Tidak semua budaya asing memiliki sifat yang baik bagi kehidupan masyarakat setempat. Namun juga tidak semua budaya asing membawa sifat kejelekan bagi kehidupan masyarakat setempat. Pada kenyataannya tidak semua anggota masyarakat dapat menerima budaya asing yang masuk di lingkungannya, dan golongan masyarakat yang paling mudah menyerap budaya asing adalah kaum muda atau anak-anak remaja. Budaya asing dapat dengan mudah diserap oleh anak-anak remaja melalui sarana teknologi informasi yang canggih dan sulit dicegah dengan sarana pengawasan orang tua atas dasar nilai-nilai konvensional. Untuk itulah kita harus selektif dalam menyerap budaya asing yang masuk ke negara kita. 
Kita tidak dapat menutup mata atas masuknya budaya asing ke dalam negara kita, karena hal ini merupakan suatu resiko yang harus diterima sebagai pengaruh globalisasi akibat kemajuan ilmu pengetahuan dan teknologi. Namun kita juga tidak dapat membiarkan begitu saja pengaruh budaya asing yang merusak kaum generasi muda bangsa khususnya para remaja kita.

Ada beberapa hal negatif pengaruh budaya asing terhadap para remaja, antara lain gaya hidup konsumtif, gaya hidup mewah, pola hidup bebas (free sex, tidak mengenal sopan santun setempat, kebebasan berpakaian yang mengundang birahi, penggunaan obat-obat terlarang, minuman keras dan sebagainya). Dengan meniru budaya asing tersebut para remaja beranggapan bahwa dirinya telah memenuhi sebagai gaya hidup orang modern. Untuk memenuhi anggapan tersebut bagi remaja yang tidak memiliki dana/uang terutama para remaja dari keluarga ekonomi lemah dan agar terlaksana gaya hidup yang diinginkan, mereka akan melakukan segala cara untuk mewujudkannya dan bahkan menjadi delinkuen. Sedangkan para remaja dari keluarga kelas ekonomi menengah ke ataspun banyak yeng meniru dan menyerap budaya asing dengan begitu saja. Mereka dapat pula menjadi remaja delinkuen karena ketatnya pengaruh orang tua untuk mempertahankan pola hidup tradisional, dan dapat juga dikarenakan terlalu longgarnya pengawasan orang tua terhadap anak-anaknya.

Untuk itulah dengan pengaruh budaya asing yang masuk ke negara kita maka kita harus selalu waspada dan melakukan upaya-upaya antisipasi agar kebudayaan kita sendiri tetap dapat bertahan dengan baik. Ada baiknya kita perhatikan apa yang dikemukakan William A Haviland (1988: 353) bahwa semua kebudayaan harus menemukan keseimbangan yang teliti di antara kebutuhan individu dan masyarakat. Kalau kepentingan masyarakat menjadi dominan, individu mengalami tekanan terlalu berat. Manifestasinya dapat meliputi segala macam kegiatan antisosial, termasuk kejahatan, penyalahgunaan narkotika, atau sekedar menjauhkan diri, dan kalau berjalan terlalu jauh, akibatnya dapat berupa keruntuhan kebudayaan dengan perubahan-perubahan yang disertai kekerasan. 


\section{Penutup}

Masa remaja adalah masa yang pasti dialami oleh setiap manusia. Pada usia remaja ini manusia mengalami proses pembentukan diri menjadi manusia dewasa dengan segala problematikanya. Usia remaja sangat riskan karena banyak pengaruh baik dari dalam maupun dari luar dalam proses pembentukan diri. Masa usia remaja inilah terjadi proses perubahan menuju kepada proses pematangan kepribadian yang penuh dengan pemunculan sifat-sifat pribadi yang sesungguhnya yang harus berbenturan dengan rangsang-rangsang dari luar. Berbagai macam benturan dan gesekan inilah yang sering menimbulkan persoalan bagi remaja yang lemah mental, jiwa dan rohaninya yang kadang-kadang diujudkan pada suatu tindakan yang menyimpang yang sering orang menyebutnya dengan "kenakalan remaja". Tindakan-tindakan yang menyimpang dengan sebutan "kenakalan remaja" ini oleh banyak orang digolongkan dalam tindakan-tindakan yang bersifat amoral, perkelahian antar remaja, dan sebagainya, sampai pada tindak kejahatan.

Sedangkan kenakalan remaja yang tergolong non-kriminal termasuk dalam jenis tingkah laku bermasalah taraf kuat yang pasip atau pengunduran diri atau "withdrawal", yaitu bentuk tingkah laku yang menunjukkan ada kecenderungan putus asa dan merasa tidak aman, sehingga menarik diri dari kegiatan dan takut memperlihatkan usaha-usahanya. Remaja yang mengalami masalah jenis ini cenderung tertarik pada kesenangan-kesenangan yang sifatnya menyendiri, apatis terhadap kegiatan masyarakat atau sekolah. Remaja ini suka mengasingkan diri, menghindarkan diri dari kegiatan yang menumbuhkan kontak dengan orang lain. Perasaannya sangat peka dan mudah terluka, cepat tersinggung dan membesar-besarkan kekurangannya sendiri, dengan gejala umum sering menyendiri, melamun, apatis tidak bergairah, sangat mudah tersinggung, sangat mudah panik, sangat mudah bingung, sehingga cenderung menjadi peminum, pemabuk, penghisap candu, narkotika, menjadi morfinis dan sebagainya, bahkan tega untuk bunuh diri.

Pola perilaku anak yang menyimpang dapat disebabkan oleh pendidikan keluarga yang tidak bisa memberikan kasih sayang. Sikap hidup 
orang tua yang penuh kekerasan memberikan pengalaman hidup bagi anak dan sewaktu-waktu dapat direproduksi dan direfleksikan dalam kehidupan anak di luar keluarganya seperti bentuk perilaku jahat atau biasa disebut delinquency. Masuknya budaya asing ke dalam negeri pasti akan membawa pengaruh terhadap pola perilaku masyarakat setempat, dan pengaruh tersebut akan menimbulkan dampak positif maupun negatif. Budaya asing berpotensi mengubah cara berpikir, cara bekerja dan cara hidup, bahkan dapat merubah kebudyaan yang sudah ada.

Tidak semua budaya asing memiliki sifat yang baik bagi kehidupan masyarakat setempat. Namun juga tidak semua budaya asing membawa sifat kejelekan bagi kehidupan masyarakat setempat. Tidak semua anggota masyarakat dapat menerima budaya asing yang masuk di lingkungannya, dan golongan masyarakat yang paling mudah menyerap budaya asing adalah kaum muda atau anak-anak remaja. Budaya asing dapat dengan mudah diserap oleh anak-anak remaja melalui sarana teknologi informasi yang canggih dan sulit dicegah dengan sarana pengawasan orang tua atas dasar nilai-nilai konvensional. Masuknya budaya asing ke dalam negeri akan membawa pengaruh terhadap pola perilaku masyarakat setempat, dan pengaruh tersebut akan menimbulkan dampak positif maupun negatif. Bila pengaruh budaya asing itu berdampak positif pasti akan membawa kemajuan dan kebaikan hidup masyarakat setempat, namun bila berdampak negatif maka kehancuranlah yang akan diperolehnya. Budaya asing berpotensi mengubah cara berpikir, cara bekerja dan cara hidup, bahkan dapat merubah kebudyaan yang sudah ada.

Pengaruh negatif budaya asing terhadap para remaja, antara lain gaya hidup konsumtif, gaya hidup mewah, pola hidup bebas (free sex, tidak mengenal sopan santun setempat, kebebasan berpakaian yang mengundang birahi, penggunaan obat-obat terlarang, minuman keras dan sebagainya). Dengan meniru budaya asing tersebut para remaja beranggapan bahwa dirinya telah memenuhi sebagai gaya hidup orang modern. Untuk memenuhi anggapan tersebut bagi remaja yang tidak memiliki dana/uang terutama para remaja dari keluarga ekonomi lemah dan agar terlaksana gaya hidup yang 
diinginkan, mereka akan melakukan segala cara untuk mewujudkannya dan bahkan menjadi delinkuen. Sedangkan para remaja dari keluarga kelas ekonomi menengah ke ataspun banyak yeng meniru dan menyerap budaya asing dengan begitu saja. Mereka dapat pula menjadi remaja delinkuen karena ketatnya pengaruh orang tua untuk mempertahankan pola hidup tradisional, dan dapat juga dikarenakan terlalu longgarnya pengawasan orang tua terhadap anak-anaknya

\section{Daftar Pustaka}

Abidin, Zaenal A. 2006. Metode Rehabilitasi Remaja Korban Narkoba. Tasikmalaya: PP Suryalaya.

Eddy MT. Sianturi, SSi dan Nafsiah, SP, $\underline{\text { Strategi Pengembangan }}$ Perbatasan Wilayah Kedaulatan. buletinglitbang@ dephan.go.id

Hendrojono (2005), Kriminologi Pengaruh Perubahan Masyarakat dan Hukum, Surabaya: Srikandi,

Kartini Kartono (1992), Patologi Sosial 2 Kenakalan Remaja, Jakarta: Rajawali Pers

Sarlito Wirawan (1997), Psikologi Remaja, Jakarta: Rajawali Pers.

Soerjono Soekanto (2004). Sosiologi Keluarga. Jakarta: Rineka Cipta.

Sudarsono (1995), Kenakalan Remaja, Jakarta: Rineka Cipta.

William A Haviland (1988), Antropologi, edisi keempat. (terjemahan R.G Soekadijo), Jakarta: Erlangga.

Tajul Arifin, AS. 1985. Ibadah Sebagai Metode Pembinaan Korban Penyarahgunaan Narkotika dan Kenakalan Remaja. Tasikmalaya: Yayasan Serba Bakti Pondok Pesantren Suryalaya. 